\title{
Model Pembelajaran Generatif melalui Media Animasi Berbasis Flash dan Video Ditinjau dari Keterampilan Generik Dan Keingintahuan
}

\author{
A. H. MOESTOFA \\ SMP Negeri 1 Kanor Bojonegoro \\ *email: ahmustofa@yahoo.com
}

Manuscript received: 14 Desember 2014 Revision accepted: 26 Januari 2015

\begin{abstract}
Tujuan penelitian untuk mengetahui pengaruh model pembelajaran generatif melalui media animasi berbasis flash dan video, keterampilan generik, keingintahuan dan interaksinya terhadap prestasi belajar. Penelitian ini menggunakan metode eksperimen. Populasi penelitian adalah seluruh siswa kelas VIII SMP Negeri 1 Kanor Bojonegoro tahun pelajaran 2011/2012. Sampel diperoleh dengan teknik cluster random sampling terdiri dari 2 kelas VIII E dan VIII D. Teknik pengumpulan data dengan menggunakan metode tes untuk prestasi belajar kognitif dan keterampilan generik, metode angket untuk keingintahuan, serta metode observasi untuk mendapatkan data prestasi belajar afektif dan psikomotor. Data dianalisis menggunakan anava tiga jalan dengan desain faktorial $2 \times 2 \times 2$ menggunakan SPSS17. Berdasarkan hasil analisis disimpulkan bahwa: 1. penerapan model pembelajaran generatif dalam kegiatan pembelajaran dapat mengatasi kesulitan peserta didik dalam mengerjakan soal yang bersifat aplikatif; 2. pemanfaatan media flash dan video dapat meningkatkan motivasi dalam belajar dan memudahkan siswa dalam mempelajari materi sistem peredaran darah sehingga siswa yang belajar dengan menggunakan media animasi berbasis flash memiliki prestasi belajar kognitif, afektif dan psikomotor lebih baik dari pada siswa yang belajar dengan menggunakan media video; 3. tingkat keterampilan generik siswa memiliki pengaruh yang signifikan terhadap prestasi belajar sehinga siswa yang memiliki keterampilan generik tinggi memperoleh prestasi kognitif, afektif dan psikomotor lebih baik dari pada siswa yang memiliki keterampilan generik rendah; 4. tingkat keingintahuan memiliki pengaruh yang signifikan terhadap proses pembelajaran yang dilakukan siswa dan prestasi belajar. Siswa dengan tingkat keingintahuan tinggi memperoleh prestasi belajar kognitif, afektif dan psikomotor lebih baik dari pada siswa yang memiliki keingintahuan rendah; 5 . media flash dan video memiliki karakteristik yang berbeda, masing-masing memiliki kelebihan dan kekurangan. Apabila keduanya diinteraksikan dengan keterampilan generik dalam suatu pembelajaran akan memberikan pengaruh yang sangat kecil terhadap prestasi belajar; 6. keterampilan generik dan keingintahuan merupakan dua hal yang saling independen, sehingga apabila keduanya diinteraksikan tidak memberikan pengaruh yang signifikan terhadap prestasi belajar.
\end{abstract}

Keywords: Model pembelajaran generatif, keterampilan generik, keingintahuan, sistem peredaran darah manusia

\section{LATAR BELAKANG}

Peraturan Pemerintah Nomor 19 Tahun 2005 tentang Standar Nasional Pendidikan mengamanatkan bahwa hendaknya proses pembelajaran pada satuan pendidikan diselenggarakan secara interaktif, inspiratif, menyenangkan, menantang, memotivasi peserta didik untuk berpartisipasi aktif, serta memberikan ruang yang cukup bagi prakarsa, kreativitas, dan kemandirian sesuai dengan bakat, minat dan perkembangan fisik serta psikologis peserta didik. Sementara itu Carin dan Sund (1975) menyatakan bahwa sains mengandung empat hal yaitu: konten atau produk, proses atau metode, sikap, dan teknologi. Sains sebagai konten atau produk mengandung arti bahwa di dalam sains terdapat fakta-fakta, hukumhukum, prinsip-prinsip, dan teori-teori yang sudah diterima kebenarannya. Sains sebagai proses atau metode berarti bahwa sains merupakan suatu proses atau metode untuk mendapatkan pengetahuan. Sains sebagai sikap berarti bahwa sains dapat berkembang karena adanya sikap tekun, teliti, terbuka, dan jujur. Sains sebagai teknologi mengandung pengertian bahwa sains terkait dengan peningkatan kualitas kehidupan. Jika sains mengandung keempat hal tersebut, maka dalam pendidikan sains di sekolah seyogyanya siswa dapat mengalami keempat hal tersebut, sehingga pemahaman siswa terhadap sains menjadi utuh dan dapat digunakan untuk mengatasi permasalahan hidupnya.

Berkaitan dengan idealisme pendidikan di atas, ternyata kemampuan sains peserta didik di Indonesia dalam bidang sains belum memberikan hasil yang memuaskan. Hal ini tampak dari studi yang dilakukan oleh The Programme for International Student Assessment (PISA) tahun 2006 diperoleh hasil bahwa kemampuan literasi sains siswa Indonesia berada pada peringkat ke-50 dari 57 negara. Survey yang sama dilakukan oleh The Trends in International Mathematics and Science Study (TIMSS) yang dilaksanakan pada bulan Mei 2007 secara bersamaan di seluruh Indonesia menunjukkkan bahwa kemampuan dalam bidang sains anak Indonesia berada pada posisi ke 35 dari 49 negara peserta.

Sejalan dengan hasil survey di atas, pembelajaran di SMP Negeri 1 Kanor Bojonegoro cenderung berpusat pada guru (teacher center), guru belum menerapkan model pembelajaran yang sesuai dengan karakteristik materi pelajaran, guru belum menggunakan media elektronik yang memungkin siswa dapat mengetahui 
mekanisme peredaran darah secara utuh, guru belum melatihkan keterampilan sains dasar, sehingga siswa akan mengalami kesulitan bila dihadapkan dengan soal yang bersifat penerapan.

Bertolak dari temuan-temuan dalam proses pembelajaran yang mengakibatkan rendahnya kemampuan siswa dalam mengerjakan soal yang bersifat penerapan seperti yang telah diuraikan di atas, maka peneliti menawarkan solusi dengan menggunakan model pembelajaran generatif. Model pembelajaran ini menekankan pengintegrasian secara aktif pengetahuan baru dengan menggunakan pengetahuan yang sudah dimiliki siswa. Selain itu, karena materi pelajaran sistem peredaran darah termasuk abstrak maka digunakan media animasi berbasis flash dan video sehingga siswa mempunyai gambaran yang kongkret dan mudah belajar.

Tujuan yang ingin dicapai dalam penelitian ini adalah untuk mengetahui pengaruh model pembelajaran generatif melalui media animasi berbasis flash dan video, ketrampilaan generik, keingintahuan dan interaksinya terhadap prestasi belajar siswa.

\section{METODE}

Penelitian dilaksanakan di SMP Negeri 1 Kanor. Jl. Raya Kanor Kabupaten Bojonegoro. Telp. (0353) 7709919. Kegiatan penelitian dilaksanakan pada bulan Oktober 2011 sampai dengan bulan Juni 2012. Penelitian ini termasuk penelitian eksperimen. Kelompok eksperimen I menggunakan media animasi berbasis flash dan kelompok II menggunakan media video.

Rancangan penelitian dalam penelitian ini disusun sesuai dengan variabel-variabel yang terlibat. Data yang diperoleh kemudian dianalisis menggunakan uji anava tiga jalan $2 \times 2 \times 2$. Teknik pengambilan sampel yang digunakan dalam penelitian ini adalah teknik cluster random sampling. Teknik pengumpulan data pada penelitian ini adalah tes, angket dan observasi. Tes digunakan untuk mengumpulkan data tentang keterampilan generik dan prestasi belajar biologi. Sedangkan angket digunakan untuk mengumpulkan data keingintahuan.

Untuk menguji validitas soal tes digunakan rumus teknik korelasi Product Moment dari Karl Pearson. Uji normalitas data yang digunakan adalah uji KolmogorofSmirnof yang terdapat pada software SPSS dan uji homogenitas digunakan adalah Levene Test yang membandingkan varians terbesar dengan varians terkecil. Kemudian Pengujian hipotesis pada penelitian ini menggunakan anava tiga jalan $2 \times 2 \times 2$ dengan bantuan software SPSS 17.

\section{HASIL DAN PEMBAHASAN}

Berikut ini disajikan data rata-rata prestasi belajar berdasarkan media pembelajaran.

Tabel 1. Rata-rata Prestasi Belajar Berdasarkan Media Flash dan Video

\begin{tabular}{cccc}
\hline \multirow{2}{*}{ Media } & \multicolumn{3}{c}{ Prestasi Belajar } \\
\cline { 2 - 4 } & Kognitif & Afektif & Psikomotor \\
\hline Flash & 80,77 & 82,61 & 80,87 \\
Video & 73,66 & 76,55 & 74,62 \\
\hline
\end{tabular}

Dari ranah belajar kognitif, afektif dan psikomotor tersebut ternyata siswa yang belajar dengan menggunakan media flash memperoleh nilai prestasi belajar lebih baik dari pada siswa yang belajar dengan menggunakan media video. Data rata-rata prestasi belajar berdasarkan keterampilan generik disajikan pada tabel 2.

Tabel 2. Rata-rata Prestasi Belajar Berdasarkan Keterampilan Generik

\begin{tabular}{cccc}
\hline Media & Min & Max & Rata-rata \\
\hline Flash & 61 & 95 & 81 \\
Video & 58 & 92 & 75 \\
\hline Selisih & 3 & 3 & 6 \\
\hline
\end{tabular}

Pada tabel 2 terlihat bahwa prestasi belajar bila ditinjau dari keterampilan generik, kelompok media flash memperoleh nilai lebih baik dari kelompok media video.

Tabel 3. Rata-rata Prestasi Belajar berdasarkan Keingintahuan

\begin{tabular}{cccc}
\hline Media & Min & Max & Rata-rata \\
\hline Flash & 61 & 95 & 81 \\
Video & 58 & 92 & 74 \\
\hline Selisih & 3 & 3 & 7 \\
\hline
\end{tabular}

Pada Tabel 3 terlihat bahwa prestasi belajar bila ditinjau dari keingintahun didapatkan hasil kelompok media flash memperoleh hasil belajar lebih baik dari kelompok media video

Tabel 4. Rangkuman Hasil Uji Anava Tiga Jalan

\begin{tabular}{|c|c|c|c|c|}
\hline \multirow[b]{2}{*}{ No. } & \multirow[b]{2}{*}{ Yang diUji } & \multicolumn{3}{|c|}{$p$-Value } \\
\hline & & Kognitif & Afektif & $\begin{array}{l}\text { Psiko } \\
\text { motor }\end{array}$ \\
\hline 1 & Media & 0.009 & 0.024 & 0.014 \\
\hline 2 & $\begin{array}{l}\text { keterampilan_ } \\
\text { generik }\end{array}$ & 0.001 & 0.001 & 0.001 \\
\hline 3 & $\begin{array}{l}\text { Keingin tahuan } \\
\text { media* }\end{array}$ & 0.000 & 0.000 & 0.000 \\
\hline 4 & $\begin{array}{l}\text { keterampilan } \\
\text { generik }\end{array}$ & 0.337 & 0.631 & 0.647 \\
\hline 5 & $\begin{array}{l}\text { media } * \\
\text { keingintahuan }\end{array}$ & 0.590 & 0.609 & 0.765 \\
\hline 6 & $\begin{array}{l}\text { keterampilan } \\
\text { generik * } \\
\text { keinointahuan }\end{array}$ & 0.305 & 0.283 & 0.193 \\
\hline 7 & $\begin{array}{l}\text { media * } \\
\text { keterampilan_ } \\
\text { generik* } \\
\text { keingintahuan }\end{array}$ & 0.260 & 0.250 & 0.293 \\
\hline
\end{tabular}

Hipotesis 1

Hasil penelitian tentang penggunaan media animasi flash dan video dalam pembelajaran diperoleh nilai $\mathrm{F}$ hitung $=$ 
7,463 dengan probabilitas p-value $=0,009$, berarti ada perbedaan pengaruh penggunaan media flash dan video terhadap prestasi belajar kognitif siswa. Pada uji anava afektif diperoleh nilai $\mathrm{F}$ hitung $=5,443$ dengan probabilitas p-value $=0,024$ berarti ada perbedaan pengaruh penggunaan media flash dan video terhadap prestasi belajar afektif siswa. Sedangkan pada uji anava psikomotor diperoleh nilai $F$ hitung $=6,435$ dengan probabilitas $\mathrm{p}$-value $=0,014$. Karena $\mathrm{p}$-value $<0,05$, berarti ada perbedaan pengaruh penggunaan media flash dan video terhadap prestasi belajar psikomotor siswa.

Dari ketiga hasil uji anava yang meliputi ranah kognitif, afektif dan psikomotor menunjukkan bahwa ada perbedaan pengaruh penggunaan media flash dan video terhadap prestasi belajar. Materi dalam pembelajaran ini adalah system peredaran darah. Karena sistem peredaran darah termasuk abstrak dalam arti tidak bisa melihat langsung mekanismenya maka diperlukan media yang dapat mengkongkritkan informasi sehingga siswa akan lebih mudah memahami materi pelajaran dan lebih bermakna karena tersimpan dalam struktur kognitif siwa. Sebagaimana teori belajar yang kemukakan oleh Ausubel (dalam Dahar, 1989). Dalam hal yang sama dimana landasan teori yang diungkapkan oleh Asyhar (2011) bahwa penggunaan teknologi sebagai media pembelajaran dapat meningkatkan produktifitas pendidikan dan dapat memberikan dasar yang lebih ilmiah dalam pembelajaran.

Nilai rata-rata hasil belajar kognitif, afektif dan psikomotor siswa yang menggunakan media flash mempunyai prestasi belajar lebih baik dari pada siswa yang belajar dengan menggunakan media video. Hal ini dikarenakan pembelajaran dengan menggunakan media flash memberikan kesempatan kepada siswa untuk mengeksplorasi lebih jauh tentang materi pelajaran sesuai dengan yang mereka kehendaki sehingga tingkat kefahamannya lebih tinggi. Hal ini sejalan dengan penelitian Rieber (1991) yang menyatakan bahwa siswa yang belajar dengan menggunakan media animasi grafis akan lebih berhasil memahami bagian-bagian dari informasi, mengurangi resiko kesalahfamahan dan memberikan kebebasan kepada siswa untuk melakukan praktek dengan menggunakan simulasi komputer. Pendapat senada diungkapkan oleh Vethanayagam dan Hemalatha (2010) bahwa pembelajaran masalah lingkungan dengan menggunakan teknologi seperti animasi dapat memberikan cakupan yang lebih baik dalam memahami dan mengaplikasikan fenomena yang mereka pelajari. Demikian juga penelitian yang dilakukan oleh Ainsworth (2008) bahwa siswa yang belajar dengan menggunakan media animasi mempunyai nilai lebih dalam penggalian pengetahuan yang lebih komplek. Penelitian serupa juga dilakukan oleh Plass (2009) yang menyatakan bahwa disain animasi dan simulasi menjamin efektifitas pendidikan. Dari beberapa hasil penelitian dan teori pembelajaran dan kemukakan para ahli di atas dapat kiranya dapat dapat mendukung penelitian ini bahwa siswa yang belajar menggunakan media animasi akan lebih mudah menerima informasi, menyimpannya dalam memori jangka panjang sehingga prestasi balajarnya juga akan lebih baik.

\section{Hipotesis 2}

Hasil analisis penelitian tentang keterampilan generik pada ranah kognitif diperoleh nilai $F$ hitung $=12,641$ dengan probabilitas $p$-value $=0,001$. berarti ada perbedaan pengaruh antara keterampilan generik tinggi dan rendah terhadap prestasi belajar kognitif. Sedangkan pada ranah afektif diperoleh nilai $F$ hitung= 12,109 dengan probabilitas $p$-value $=0,001$ berarti ada perbedaan pengaruh antara keterampilan generik tinggi dan rendah terhadap prestasi belajar afektif. Sedangkan pada ranah psikomotor diperoleh nilai $\mathrm{F}$ hitung= 12,112 dengan probabilitas $p$-value $=0,001$, berarti ada perbedaan pengaruh antara keterampilan generik tinggi dan rendah terhadap prestasi belajar psikomotor. Dengan demikian dapat disimpulkan bahwa ada perbedaan pengaruh kektrampilan generik tinggi dan rendah terhadap prestasi belajar.

Rerata hasil belajar siswa yang memiliki keterampilan generik tinggi memberikan pengaruh yang lebih banyak dari pada siswa yang memilikit keterampilan generik rendah, baik pada ranah kognitif, afektif dan psikomotor. Keterampilan generik sains merupakan kemampuan berpikir dan bertindak (siswa) berdasarkan pengetahuan sains yang dimilikinya (Brotosiswoyo, 2001), Oleh karena itu siswa yang memiliki kemampuan berpikir sains tinggi akan memperoleh prestasi belajar yang lebih baik dari pada siswa yang memiliki kemampuan berpikir sains rendah. Prestasi belajar siswa yang memiliki keterampilan generik tinggi lebih baik dari siswa yang memiliki keterampilan generik rendah karena siswa yang memiliki keterampilan generik tinggi akan mengoptimalkan ragam keterampilan generik yang dimiliki, seperti pengamatan langsung maupun tak langsung, kesadaran skala, bahasa simbolik, kerangka logik, sebab akibat, pemodelan, inferensi maupun abstraksi. Hal ini mendukung teori yang dikemukakan oleh Paquette (2007) yang menyatakan bahwa keterampilan generik adalah proses yang dapat diaplikasikan pada beberapa pengetahuan baru. Karena siswa yang memiliki keterampilan generik tinggi dapat menerapkan pengetahuan dan keterampilannya pada masalah yang baru sehingga kelompok ini tidak kesulitan bila menjumpai kasus yang bersifat aplikatif. Dengan demikian siswa yang memiliki keterampilan generik tinggi akan lebih mudah mengerjakan soal yang bersifat penerapan sehingga prestasi belajarnya akan lebih baik dari kelompok generik rendah.

\section{Hipotesis 3}

Hasil analisis penelitian tentang keingintahuan diperoleh nilai $\mathrm{F}$ hitung $=39,360$ dengan probabilitas $p$-value $=$ 0,000 berarti ada perbedaan pengaruh antara keingintahuan tinggi dan rendah terhadap prestasi belajar kognitif. Sedangkan pada ranah afektif diperoleh nilai $\mathrm{F}$ hitung $=50,648$ dengan probabilitas $p$-value $=0,000$ berarti ada perbedaan pengaruh antara keingintahuan tinggi dan rendah terhadap prestasi belajar afektif. 
Sedangkan pada ranah psikomotor diperoleh nilai $\mathrm{F}$ hitung $=50,103$ dengan probabilitas $p$-value $=0,000$ berarti ada perbedaan pengaruh antara keingintahuan tinggi dan rendah terhadap prestasi belajar psikomotor.

Hasil penelitian ini menguatkan teori yang dikembangkan oleh Kashdan dan Robert (dalam Gulten, 2011) yang menyatakan bahwa Keingintahuan sangat penting dalam pendidikan karena dapat menekan siswa untuk belajar lebih baik. Selain itu hasil penelitian ini juga menjelaskan bahwa mahasiswa yang memiliki tingkat keingintahuan tinggi memiliki memiliki prestasi belajar yang lebih baik dari mahasiswa yang memiliki tingkat keingintahuan rendah. Siswa yang memiliki keingintahuan tinggi akan mengoptimalkan segala kompetensi keingintahuan seperti pengajuan pertanyaan, penalaran, adanya eksplorasi lebih lanjut, daya pikir, pemenuhan kepuasan, adanya dorongan/rangsangan untuk berfikir. Dengan demikian siswa yang tingkat keingintahuannya tinggi akan lebih memahami materi pelajaran yang pada akhirnya akan mendapatkan prestasi yang lebih baik dari pada siswa yang tingkat keingintahuannya rendah.

\section{Hipotesis 4}

Hasil penelitian tentang interaksi antara media pembelajaran (flash dan video) terhadap prestasi belajar kognitif diperoleh nilai $\mathrm{F}$ hitung $=0,937$ dengan $p$-value $=$ 0,337 berarti Interaksi antara media dan keterampilan generik tidak memberikan pengaruh signifikan terhadap Prestasi Belajar kognitif. Sedangkan pada ranah afektif didapatkan nilai $\mathrm{F}$ hitung $=0,233$ dengan $p$-value $=$ 0,631 . Oleh karena $p$-value $>0,05$; maka Ho diterima, berarti interaksi antara media dan keterampilan generik tidak memberikan pengaruh signifikan terhadap prestasi Belajar afektif. Sedangkan interaksi antara media (flash dan video) terhadap prestasi belajar psikomotor didapatkan nilai $\mathrm{F}$ hitung $=0,212$ dengan $p$-value $=0,647$, berarti interaksi antara media dan keterampilan generik tidak memberikan pengaruh signifikan terhadap prestasi belajar psikomotor.

Dari hasil analisis varian di atas dapat dijelaskan bahwa nilai yang dihasilkan dari hasil uji ini sangat kecil sehingga tidak mampu mempengaruhi atau memberikan interaksi diantara variabel yang terlibat. Karena kecilnya perbedaan rentan nilai tersebut menjadikan media flash dan video serta keterampilan generik tidak mampu memberikan pengaruh yang signifikan terhadap prestasi belajar. Dengan demikian dapat dikatakan antara media flash dan video serta keterampilan bersifat saling independen.

\section{Hipotesis 5}

Hasil penelitian tentang interaksi antara media flash dan video dengan keingintahuan terhadap prestasi belajar kognitif diperoleh nilai $\mathrm{F}$ hitung $=0,294$ dengan $p$-value $=0,590$ berarti interaksi antara media flash dan video dengan keingintahuan tidak memberikan pengaruh signifikan terhadap prestasi belajar kognitif. Sedangkan pada ranah afektif didapatkan nilai $\mathrm{F}$ hitung $=0,265$ dengan $p$-value $=0,609$ berarti interaksi antara media flash dan video dengan keingintahuan tidak memberikan pengaruh signifikan terhadap prestasi belajar afektif. Sedangkan pada ranah psikomotor diperoleh nilai $\mathrm{F}$ hitung $=0,091$ dengan $p$-value $=0,765$ berarti interaksi antara media flash dan video dengan keingintahuan tidak memberikan pengaruh signifikan terhadap prestasi belajar psikomotor.

Karena kecilnya perbedaan rentan nilai tersebut menjadikan media flash dan video serta keingintahuan tidak mampu memberikan pengaruh yang signifikan terhadap prestasi belajar. Dengan demikian dapat dikatakan antara media flash dan video serta keingintahuan bersifat saling independen.

Dari hasil analisis di atas dapat dijelaskan bahwa media pembelajaran yang diinteraksikan dengan keingintahuan menjadikan siswa memiliki prestasi belajar yang tidak berbeda dari kedua kelompok penelitian. Dengan tidak adanya perbedaan yang signifikan menunjukkan bahwa kedua variabel yang diinteraksikan dapat saling mengisi atau saling menghambat sehingga dapat mengaburkan pengaruhnya terhadap prestasi belajar. Karena kedua variabel saling independen sehingga menyebabkan tidak terjadi interaksi antara media pembelajaran (flash dan video) dan keingintahuan terhadap prestasi belajar.

\section{Hipotesis 6}

Hasil penelitian tentang interaksi antara keterampilan generik dan keingintahuan terhadap prestasi belajar kognitif diperoleh nilai $\mathrm{F}$ hitung $=1,074$ dengan $p$-value $=$ 0,305 berarti interaksi antara keterampilan generik dan keingintahuan tidak memberikan pengaruh signifikan terhadap prestasi belajar kognitif. Sedangkan pada ranah afektif diperoleh nilai $\mathrm{F}$ hitung $=1,175$ dengan $p$-value $=$ 0,283 . berarti interaksi antara keterampilan generik dan keingintahuan tidak memberikan pengaruh signifikan terhadap prestasi belajar afektif. Sedangkan pada ranah psikomotor diperoleh nilai $\mathrm{F}$ hitung $=1,739$ dengan $p$ value $=0,193$ berarti interaksi antara keterampilan generik dan keingintahuan tidak memberikan pengaruh signifikan terhadap prestasi belajar psikomotor.

Dari hasil analisis di atas dapat dijelaskan bahwa keterampilan generik yang diinteraksikan dengan keingintahuan menjadikan siswa memiliki prestasi belajar yang tidak berbeda atau perbedaan keduanya sangat kecil dari kedua kelompok penelitian. Dengan tidak adanya perbedaan yang signifikan menunjukkan bahwa kedua variabel yang diinteraksikan dapat saling mengisi atau saling menghambat sehingga dapat mengaburkan pengaruhnya terhadap prestasi belajar. Karena kedua variabel saling independen sehingga menyebabkan tidak terjadi interaksi antara keterampilan generik dan keingintahuan terhadap prestasi belajar.

\section{Hipotesis 7}

Hasil penelitian tentang interaksi antara media flash dan video, keterampilan generik dan keingintahuan terhadap prestasi belajar kognitif diperoleh nilai $\mathrm{F}$ hitung $=1,299$ dengan $p$-value $=0,260$ berarti interaksi antara Media flash dan video, keterampilan generik dan keingintahuan 
tidak memberikan pengaruh signifikan terhadap prestasi belajar kognitif. Selain itu, pada ranah afektif diperoleh nilai $\mathrm{F}$ hitung $=1,353$ dengan $p$-value $=0,250$ berarti interaksi antara media flash dan video, keterampilan generik dan keingintahuan tidak memberikan pengaruh signifikan terhadap prestasi belajar afektif. Sedangkan pada ranah psikomotor diperoleh nilai $F$ hitung $=1,126$ dengan $p$-value $=0,293$ berarti interaksi antara Media flash dan video, keterampilan generik dan keingintahuan tidak memberikan pengaruh signifikan terhadap prestasi belajar psikomotor.

Pada hasil uji anava baik pada ranah kognitif, afektif dan psikomotor didapatkan selisih perbedaan angka signifikan yang kecil, demikian juga pada deskripsi hasil tes belajar kelompok media, keterampilan generik dan keingintahuan didapatkan hasil yang sama. Dari hasil analisis di atas dapat dijelaskan bahwa media flash dan video yang diinteraksikan dengan keterampilan generik dan keingintahuan menjadikan prestasi belajar yang diperoleh dari kedua kelompok penelitian tidak berbeda. Dengan tidak adanya perbedaan yang signifikan menunjukkan bahwa ketiga variabel yang diinteraksikan dapat saling mengisi atau saling menghambat sehingga dapat mengaburkan pengaruhnya terhadap prestasi belajar. Karena ketiga variabel saling independen sehingga menyebabkan tidak terjadi interaksi antara media flash dan video, keterampilan generik dan keingintahuan terhadap prestasi belajar.

\section{KESIMPULAN}

Berdasarkan hasil penelitian dan pembahasan diperoleh kesimpulan sebagai berikut:

Penerapan model pembelajaran generatif dalam kegiatan pembelajaran dapat mengatasi kesulitan peserta didik dalam mengerjakan soal yang bersifat aplikatif.

Pemanfaatan media flash dan video dapat meningkatkan motivasi dalam belajar dan memudahkan siswa dalam mempelajari materi sistem peredaran darah sehingga siswa yang belajar dengan menggunakan media animasi berbasis flash memiliki prestasi belajar kognitif, afektif dan psikomotor lebih baik dari pada siswa yang belajar dengan menggunakan media video.

Tingkat keterampilan generik siswa memiliki pengaruh yang signifikan terhadap prestasi belajar sehinga siswa yang memiliki keterampilan generik tinggi memperoleh prestasi kognitif, afektif dan psikomotor lebih baik dari pada siswa yang memiliki keterampilan generik rendah. Tingkat keingintahuan memiliki pengaruh yang signifikan terhadap proses pembelajaran yang dilakukan siswa dan prestasi belajar. Siswa dengan tingkat keingintahuan tinggi memperoleh prestasi belajar kognitif, afektif dan psikomotor lebih baik dari pada siswa yang memiliki keingintahuan rendah.
Media flash dan video memiliki karakteristik yang berbeda, masing-masing memiliki kelebihan dan kekurangan. Apabila keduanya diinteraksikan dengan keterampilan generik dan keingintahuan dalam suatu pembelajaran tidak memberikan pengaruh yang signifikan terhadap prestasi belajar.

Dalam upaya meningkatkan kemampuan siswa dalam menghadapi soal yang bersifat penerapan, Guru dapat menerapkan model pembelajaran generatif dalam kegiatan belajar mengajar. Dalam mempelajari materi tentang sistem peredaran darah diharapkan guru menggunakan media animasi flash karena siswa akan bebas mengeksplorasi pengetahuan dan akan mengahasilkan prestasi belajar lebih baik. Sebelum pelaksanaan pembelajaran dengan menggunakan media animasi flash, guru hendaknya mengecek kesiapan peralatan (laptop) dan mencoba dulu software-nya.

\section{DAFTAR PUSTAKA}

Asyhar, R. (2011). Kreatif Mengembangkan Media Pembelajaran. Jakarta: Gaung Persada Press.

Carin, A.A. \& Sund, R.B. (1975). Teaching Science Through Discovery, Columbus.Ihio: Charles E. Merrill Publishing Company.

Depdiknas. (2005). Peraturan Pemerintah Nomor 19 Tahun 2005 tentang StandartNasional Pendidikan. Jakarta: Biro Hukum dan organisasi.

Gulten, D.C., Yaman, Y., Deringol, Y., Ozsary, I. (2011). Investigating the relationship between curiosity level and computer self efficacy belief of elementary teachers candidate. The Turkish Online J. Educational Technology. 10(4): 248-254.

PISA. (2009). Results: What Makes a School Succesful?Resources, Policies and Practices. OECD.

Paquette, G. (2007). An Ontologi and Software Frame Work for Competency Modelling and Management. Educational Technology and Society.

Plass, JL, Homer, BD, Hayward, AO. (2009). Design factor for educationally effective animations and simulations. J.Comput High Educ.

Rieber, LP. (1991). Animation, Incidental Learning and Continuing Motivation. Journal of Educational Psychology. 83(3): 318-328.

TIMSS. (2007). Mathematic and Science Literacy, advanced Matematics and Physics. IEA. http://timss:bc.edu/

Vethanayagam, AL, \& Hemalatha. (2010). Effect of Environmental Education to School Through Animation Based Educational Video. Language in India, 10:10-16. 